\title{
Evaluation on antioxidative capacity, nephroprotective effect, and DNA damage protection of mixed low potassium vegetables and fruits juice powder in HEK-293 cells
}

\section{Matthawan Khamhae ${ }^{1}$, Kanyanatt Kanokwiroon ${ }^{3}$, Worrapanit Chansuwan ${ }^{2}$, Nualpun Sirinupong ${ }^{2}$}

${ }^{1}$ Functional Food and Nutrition, Faculty of Agro-Industry, Prince of Songkla University, Hatyai, Songkhla 90112, Thailand; ${ }^{2}$ Interdisciplinary Graduate School of Nutraceutical and Functional Food, Prince of Songkla University, Hatyai, Songkhla 90112, Thailand; ${ }^{3}$ Biomedical science, Faculty of Medicine, Prince of Songkla University, Hat Yai, Songkhla 90112, Thailand

Corresponding author: Nualpun Sirinupong, Ph.D. Interdisciplinary Graduate School of Nutraceutical and Functional Food, Prince of Songkla University, Hatyai, Songkhla 90112, Thailand

Submission Date: February 16 ${ }^{\text {th }}$, 2020; Acceptance Date: March 25 ${ }^{\text {th }}$, 2020; Publication Date: March $30^{\text {th }}, 2020$

Citation: Khamhae M., Kanokwiroon K., Chansuwan W., Sirinupong N.. Evaluation on antioxidative capacity, nephroprotective effect, and DNA damage protection of mixed low potassium vegetables and fruits juice powder in HEK-293 cells. Functional Foods in Health and Disease. 2020; 10(3): 111-126. DOI: https:/doi.org/10.31989/ffhd.v10i3.698

\begin{abstract}
Background: An imbalance between free radical production and antioxidant defenses is one of the multifactorial natures contributing to many disorders. One of them is chronic kidney disease (CKD). The development of novel diets to slow progression or reduces complication of CKD are highly needed. Therefore, the objective of this study was to evaluate the in vitro antioxidative capacity and nephroprotective effect of a product, mixed low potassium vegetables and fruits juice powder (MJP) in HEK-293 cells.
\end{abstract}

Methods: The produced MJP was determined for phenolics and flavonoids content. The antioxidative capacity was examined by DPPH, FRAP and ABTS assay. The cell viability to MJP and hydrogen peroxide $\left(\mathrm{H}_{2} \mathrm{O}_{2}\right)$-treated were determined by MTT assay. The intracellular antioxidative capacity was determined by co-treatment of MJP and $\mathrm{H}_{2} \mathrm{O}_{2}$-induced HEK-293 cell damage including reactive oxygen species (ROS) production, intracellular enzymes activities, and DNA damage protection.

Results: The MJP at the concentration of 5 and $10 \mathrm{mg} / \mathrm{ml}$ showed positive effects on $\mathrm{H}_{2} \mathrm{O}_{2-}$ induced HEK-293 cells protection and significantly increased cell viability. The ROS production measured by 2',7'-dichlorodihydrofluorescein diacetate (DCF) were increased in the $\mathrm{H}_{2} \mathrm{O}_{2}$ treatment approximately 2 times but significantly decreased in the MJP treatment. The result of intracellular enzymatic antioxidant markers, including superoxide dismutase (SOD) and catalase (CAT) activities were increased while the Malonaldehyde (MDA) level 
was attenuated in the co-treatment of MJP and $\mathrm{H}_{2} \mathrm{O}_{2}$-induced HEK293 cells compared with only $\mathrm{H}_{2} \mathrm{O}_{2}$-inducing. In the examination of the morphological change due to oxidative stress exhibited less nuclei fragment in the cell of MJP treatment. In addition, the isolated DNA was protected by MJP application.

Conclusion: The produced MJP contains bioactive phenolic and flavonoid compounds. MJP possesses potential antioxidative capacity through the reducing $\mathrm{H}_{2} \mathrm{O}_{2}$-induced HEK-293 cells damage and increasing the intracellular antioxidant enzymes. In addition, the nephroprotective effects of MJP related to the antioxidant enzymes was involved in the free radical scavenging. Therefore, MJP could be a functional drink for individual limiting potassium and liquid uptake.

Keywords: Antioxidative capacity, DNA damage protection, low potassium vegetables and fruits, nephroprotective, chronic kidney disease

\section{INTRODUCTION}

Oxidative stress is defined as an imbalance between endogenous antioxidant defense mechanisms and the production of reactive oxygen species (ROS) and reactive nitrogen species (RNS) [1]. The high levels of imbalance can cause cell injury and damage through modifications of proteins, lipids, and DNA. Increased oxidative stress is involved in the pathophysiology of many diseases such as cardiovascular diseases (CVDs), neurodegenerative diseases (NDs), macular degeneration (MD), biliary diseases, cancer, chronic kidney disease (CKD) [2]. The cellular antioxidant enzymes play the important role of protecting the cells and organisms from the oxidative damage. For example, superoxide dismutase (SOD) acts as a catalyst to convert superoxide radicals $\left(\mathrm{O}_{2}{ }^{-}\right)$into oxygen and hydrogen peroxide. Catalase convert hydrogen peroxide $\left(\mathrm{H}_{2} \mathrm{O}_{2}\right)$ into water and oxygen to protect the cells from accumulation of $\mathrm{H}_{2} \mathrm{O}_{2}$ [3]. In case of $\mathrm{CKD}$ patients, increased production of ROS, impaired nonenzymatic or enzymatic antioxidant defense mechanisms, and other risk factors including gene polymorphisms, uremic toxins (indoxyl sulfate), deficiency of arylesterase/paraoxonase, hyperhomocysteinemia, dialysisassociated membrane bioincompatibility, and endotoxin can inhibit normal cell function by damaging cell lipids, arachidonic acid derivatives, carbohydrates, proteins, amino acids, and nucleic acids $[2,4,5]$.

Epidemiological studies have found that consumption of vegetables and fruits has a significant role in reducing the risk of cardiovascular disease and other chronic diseases [6]. Current evidence and studies suggests that antioxidant therapy in pre-dialysis chronic kidney patients may prevent progression to end-stage kidney disease (ESKD) [7, 8, 9]. Consumption of antioxidants through diet and supplements is expected to remove ROS from the body system and provide health benefits. Several studies demonstrated that medicinal plants and fruits are a rich source of antioxidant compounds such as phenolics, flavonoids, vitamins, and alkaloids, which decrease the incidence of oxidative stress and associated diseases [10,11]. Previous studies showed that the phytochemicals, especially phenolics, in vegetables and fruits are the major bioactive compounds exhibited potent antioxidant effects $[12,13,14]$ and total phenolic contents affects to the antioxidant capacity in vegetables and fruits $[15,16]$.

Chronic kidney disease is a global health problem (11-13\%; 200 million) [17]. In Thailand, the prevalence of chronic kidney disease and kidney failure were 17.6\% (7.6 million) and 0.9\% $(70,000)$ [18]. Patients with kidney failure are subjected to strict restriction on the uptake of potassium and water quantity, , they cannot freely consume fruits, vegetables, and water in the large amounts [19]. Taken together, the development of nutritive dried powder food product 
for specific or limit a nutrient potassium and water for CKD patients is necessary. Therefore, the objectives of this study were to evaluate the antioxidative capacity of the product (mixed low potassium vegetables and fruits juice powder (MJP)) and its in vitro molecular mechanisms on $\mathrm{H}_{2} \mathrm{O}_{2}$ induced oxidative stress in HEK-293 cells.

\section{MATERIALS AND METHODS \\ Preparation of MJP}

Vegetables including mungbean sprout (Vigna radiata (L.) $R$. Wilczek), napa cabbage (Brassica rapa subsp. chinensis (L.)) and winter melon (Benincasa hispida (Thunb.) Cogn.), and fruits including apple (Malus domestica Borkh.'Red Fuji'), watermelon (Citrullus lanatus (Thunb.) Matsum. 'Kinaree'), and pineapple (Ananas comosus (L.) Merr. 'Batavia / Si Racha') which were purchased from local market in Hatyai, Songkla, Thailand. Juices were extracted by HUROM-H22 extractor and mixed all together in an appreciate amount. The mixed juice powder was made by a spray dryer and kept at $-20^{\circ} \mathrm{C}$ for further analysis. All assays will be performed in at least three individual experiments.

\section{Determination of polyphenol content}

Total Phenolics content was determined [20]. Briefly, $12.5 \mu \mathrm{L}$ of the juice sample (mg MJP powder/mL water) was mixed with $50 \mu \mathrm{L}$ of distilled water and then mixed with $12.5 \mu \mathrm{L}$ Foilin-Ciocalteu reagent and allowed to stand for $5 \mathrm{~min}$ at room temperature. Then, $125 \mu \mathrm{L}$ of $7 \% \mathrm{Na}_{2} \mathrm{CO}_{3}$ and $100 \mu \mathrm{L}$ of distilled water were added to the reaction mixture, followed by incubation at room temperature for 30 minutes. The absorbance was detected by a microplate reader at $760 \mathrm{~nm}$ and converted to total phenolic ( $\mu \mathrm{g}$ gallic acid equivalent, (GAE)/g dry weight).

Total Flavonoids content was determined [21]. Briefly, a $150 \mu \mathrm{L}$ of juice sample was added to $20 \mu \mathrm{L}$ of a $5 \% \mathrm{NaNO}_{2}$ solution. The mixture was left to stand at room temperature for 6 minutes, then $20 \mu \mathrm{L}$ of a $10 \% \mathrm{AlCl}_{3}$ was added and incubated at room temperature for 5 minutes, followed by adding $100 \mu \mathrm{L}$ of $1 \mathrm{M} \mathrm{NaOH}$. After incubation at room temperature for 30 minutes, the absorbance was measured at $510 \mathrm{~nm}$ and the total flavonoids content was expressed as $\mu \mathrm{g}$ quercetin equivalent (QE)/g dry weight.

\section{Determination of antioxidant properties}

DPPH assay [22] is based on the scavenging activity of the stable DPPH free radical. Briefly, $20 \mu \mathrm{L}$ of juice sample was added into $180 \mu \mathrm{L}$ of $200 \mu$ mole/L DPPH (Sigma-Aldrich, St. Louis, MO, USA) dissolved in methanol. The mixture was incubated in the dark at room temperature for 30 minutes. The absorbance was measured at $517 \mathrm{~nm}$ using the microplate reader with 96well plates. Trolox calibration solutions was used to generate the standard curve. The radical scavenging activity was expressed as $\mu$ mole Trolox equivalents (TE)/g dry weight.

FRAP assay [23] was determined with some modifications. A $300 \mathrm{mM}$ acetate buffer (pH 3.6), $10 \mathrm{mM}$ TPTZ (Sigma-Aldrich, St. Louis, MO, USA) in $40 \mathrm{mM} \mathrm{HCl}$, and $20 \mathrm{mM}$ $\mathrm{FeCl}_{3} \cdot 6 \mathrm{H}_{2} \mathrm{O}$ were prepared for stock solutions. The FRAP reagent was prepared by mixing the stock solutions in a ratio of 10:1:1 and incubated in water bath at $37^{\circ} \mathrm{C}$. Then, $20 \mu \mathrm{L}$ of the juice sample was added into $180 \mu \mathrm{L}$ of FRAP reagent and incubated in the dark at room temperature for 30 minutes. The absorbance was measured at $593 \mathrm{~nm}$ using the microplate reader with 96-well plates. Trolox was used as standard curve and the results was expressed as $\mu$ mole Trolox equivalents (TE)/g dry weight. 
ABTS assay was followed the previous study [24]. The stock solutions were prepared, 4 $\mathrm{mM}$ ABTS solution (Sigma-Aldrich, St. Louis, MO, USA) and $2.5 \mathrm{mM}$ potassium persulfate $\left(\mathrm{K}_{2} \mathrm{~S}_{2} \mathrm{O}_{8}\right)$ solution. The working ABTS solution was then prepared by mixing the two stock solutions in a ratio of 1:1 and allowed to stand in the dark at room temperature for 16 hours. The solution was diluted by mixing a $1 \mathrm{ml}$ of working ABTS solution with $9 \mathrm{ml}$ of distilled water. The juice samples $(20 \mu \mathrm{L})$ were mixed with $180 \mu \mathrm{L}$ of the diluted ABTS solution and the absorbance was measured at $734 \mathrm{~nm}$ after 30 minutes of incubation in the dark at room temperature using the microplate reader with 96-well plates. Trolox was used for standard curve and results was expressed as $\mu$ mole Trolox equivalents (TE)/g dry weight.

\section{Cell culture}

Human embryonic kidney-293 (HEK-293) cells were cultured using DMEM supplemented with $10 \%(\mathrm{v} / \mathrm{v}) \mathrm{FBS}, 1 \%(\mathrm{v} / \mathrm{v})$ L-glutamax and $1 \%(\mathrm{v} / \mathrm{v})$ penicillin streptomycin solution in a humidified atmosphere of $5 \% \mathrm{CO}_{2}$ at $37^{\circ} \mathrm{C}$. All cell culture reagents were purchased from Gibthai Co.,Ltd.

\section{Determination of cytotoxicity of MJP}

Cytotoxicity of MJP was determined by the MTT assay according to the method previously [25] with some modifications. Cells were seeded in 96-well culture plates at a density of $5 \times 10^{4}$ cells/well $(n=3)$. Cells were left to adhere on the plate for 24 hours before treated with a different concentration of MJP $(0.1-100 \mathrm{mg} / \mathrm{ml})$ for another 24 hours. The viable cells were measured after 24 hours of incubation, by adding $5 \mathrm{mg} / \mathrm{mL}$ of MTT solution (Sigma-Aldrich, St. Louis, MO, USA) and further incubating the cells for $2 \mathrm{hrs}$. The occurred formazan crystals were dissolved with DMSO. The absorbance was measured using microplate reader at a wavelength of $570 \mathrm{~nm}$ and $650 \mathrm{~nm}$ (reference). The percentage of cell viability was calculated according to the following equation (1):

$$
\text { Cell viability }(\%)=\frac{\text { Absorbance of treated cells }}{\text { Absorbance of control cells }} \times 100(1)
$$

\section{Examination of toxicity of $\mathrm{H}_{2} \mathrm{O}_{2}$ in $\mathrm{HEK}-293$ cells}

The $5 \times 10^{4}$ cells were seeded in a 96-well culture plate and were allowed to grow for 24 hours, then treated with difference concentrations of $\mathrm{H}_{2} \mathrm{O}_{2}$ in range from 0.5 to $4 \mathrm{mmole} / \mathrm{L}$ for 24 hours. The cells without $\mathrm{H}_{2} \mathrm{O}_{2}$ treated were the control. The viable cells were measured by adding $5 \mathrm{mg} / \mathrm{mL}$ of MTT solution and incubated for 2 hours. The occurred formazan crystals were dissolved with DMSO. The absorbance was measured using microplate reader at wavelength of $570 \mathrm{~nm}$ and $650 \mathrm{~nm}$ (reference). The percentage of cell viability was determined as equation 1 and $\mathrm{IC}_{50}$ of $\mathrm{H}_{2} \mathrm{O}_{2}$ was used to induce toxicity to the cells for further study.

\section{Determination of neproprotective effect of $M J P$}

Neproprotective effect of MJP was evaluated by the MTT assay [26,27]. Approximately $5 \times 10^{4}$ cells (HEK-293) were seeded in 96 well culture plate in DMEM medium with 10\% FBS, $1 \%$ L-glutamax and $1 \%$ penicillin streptomycin in a $5 \% \mathrm{CO}_{2}$ incubator. After 24 hours of incubation, the cells were exposed to MJP in growth medium to a final concentration of 0.1 , $0.5,1,5$, and $10 \mathrm{mg} / \mathrm{mL}$ MJP and $100 \mu \mathrm{L}$ of $1.57 \mathrm{mmole} / \mathrm{L} \mathrm{H}_{2} \mathrm{O}_{2}$, then incubated at $37^{\circ} \mathrm{C}$ for 
24 hours. After incubation, $100 \mu \mathrm{L}$ of the medium was removed and $10 \mu \mathrm{l}$ of MTT $(5 \mathrm{mg} / \mathrm{mL})$ was added in and incubated for 2 hours. Formazan crystals formed and dissolved using DMSO, then the absorbance was measured at $570 \mathrm{~nm}$ and $650 \mathrm{~nm}$ (reference).

\section{Examination of cell morphology}

The Hoechst 33342 was used to examine the cellular and nuclear morphology of cells modified from the previous study [28]. After the co-treatment cells with $0.1,0.5,1,5$, and $10 \mathrm{mg} / \mathrm{ml} \mathrm{MJP}$ and $\mathrm{H}_{2} \mathrm{O}_{2}$ for 24 hours., the $100 \mu \mathrm{l}$ of the medium were removed and cells were stained with $10 \mu \mathrm{l}$ of $20 \mu \mathrm{g} / \mathrm{mL}$ Hoechst 33342, which changed the morphology of what was observed under an IX-71 Olympus fluorescence microscope.

\section{Determination of ROS production}

The determination of ROS production on hydrogen peroxide $\left(\mathrm{H}_{2} \mathrm{O}_{2}\right)$-stressed HEK-293 cells was modified previous study $[29,30]$. The $5 \times 10^{4}$ HEK-293 cells were seeded in a clear-bottom and black-walled of 96-well plates and allowed the cells attach to the plate for 24 hours. Then, the cells were exposed to final concentration of $0.1,0.5,1,5$ and $10 \mathrm{mg} / \mathrm{mL} \mathrm{MJP}$ and $100 \mu \mathrm{L}$ of $1.57 \mathrm{mmole} / \mathrm{L} \mathrm{H}_{2} \mathrm{O}_{2}$ as a co-treatment. After incubation at $37^{\circ} \mathrm{C}$ for $30 \mathrm{~min}, 10 \mu \mathrm{l}$ of $100 \mu \mathrm{M}$ carboxy-2',7'-dichloro-dihydro-fluorescein diacetate (DCFH-DA) (Sigma-Aldrich, St. Louis, MO, USA) probe was added and incubated for another $30 \mathrm{~min}$. At the end of this period, the fluorescence was measured at wavelengths of $485 \mathrm{~nm}$ (excitation) and $530 \mathrm{~nm}$ (emission) with the fluorescence microplate reader (Varioskan ${ }^{\mathrm{TM}} \mathrm{LUX}$ multimode microplate reader).

\section{Determination of enzymatic antioxidant activity and Lipid oxidation product}

HEK-293 cells were cultured in $10 \mathrm{~cm}$ culture dish with confluence 80-90\% then the cells were co-treated with final concentration of $0.1,0.5,1,5,10 \mathrm{mg} / \mathrm{mL} \mathrm{MJP}$ and $100 \mu \mathrm{L}$ of 1.57 mmole/ $\mathrm{L} \mathrm{H}_{2} \mathrm{O}_{2}$ for 24 hours. The activities of superoxide dismutase (SOD), catalase (CAT), and the malondialdehyde (MDA) content were measured using assay kits (Bioassayassay kit, USA). All procedures were completely compliant with the manufacturer's instructions.

\section{Examination of DNA damage protection}

Fenton's reagent is a solution of hydrogen peroxide and a ferrous iron catalyst used for DNA damage protection assay which was modified method [31]. The sample DNA will be destroyed by Fenton's reagent. Genomic DNA was isolated from HEK-293 cells. A $0.2 \mu \mathrm{g}$ of genomic DNA was mixed with $3 \mu \mathrm{L}$ of $50 \mathrm{mM}$ phosphate buffer (pH 7.4) and $3 \mu \mathrm{L}$ of $40 \mathrm{mM} \mathrm{FeSO}_{4}$. Then, $5 \mu \mathrm{L}$ of $0.1,0.5,1,5$ and $10 \mathrm{mg} / \mathrm{mL}$ MJP were added and followed by $4 \mu \mathrm{L}$ of $1 \mathrm{mM}$ $\mathrm{H}_{2} \mathrm{O}_{2}$, the mixture was incubated at $37^{\circ} \mathrm{C}$ for 30 minutes. After that, $5 \mu \mathrm{L}$ of $1 \mathrm{mmole} / \mathrm{L}$ gallic acid was added immediately to stop the reaction. Finally, the DNA was visualized on $1 \%$ agarose gel electrophoresis. The density or intensity of genomic DNA band in each treatment were calculated by CCD, chemiluminescent and infrared fluorescent (Fusion Fx5XT Spectra/Superbright).

\section{Statistical analysis}

All data were presented as the mean \pm standard deviation (SD) of three replicate experiments. Analysis of the variance was performed on the data obtained (ANOVA). The data determined significance of difference among mean by Tukey's test. 


\section{RESULTS AND DICUSSION}

\section{Mixed low potassium vegetables and fruits juice powder (MJP)}

MJP was produced by mixed three vegetables and three fruits including of napa cabbage, mung bean sprout, winter melon, apple, watermelon, and pineapple. These are low/moderate potassium (potassium content $<200 \mathrm{mg} / 100 \mathrm{~g}$ ) plants [35]. The three vegetables and fruits types were weighted in suitable proportions. The extracted juice was obtained and mixed with a minimum amount of carrying agent for spray drying to be powder [32]. The result showed that the yield of MJP powder was $56.17 \pm 2.57 \%$. Typically, the product yield was defined as the ratio of the mass of powder collected after spray drying to the weight of total solids in the feed. The product yield was generally increased as the carrier content increased which was reported in previous studies, tamarind juice [33], and sugarcane juice [34]. However, increasing carrying agents should be considered based on various features of product such as particles characteristic, moisture content, hygroscopicity, solubility, and biological properties.

\section{Total phenolic and flavonoid contents of MJP}

The mixed low potassium vegetables and fruits juice powder was expressed for the total phenolic content as $\mu \mathrm{g}$ of gallic acid equivalent (GAE) per gram dry weight (dw) of powder exhibited a total phenolic contents of $906.94 \pm 8.97 \mu \mathrm{g}$ GAE/g dw while the total flavonoid content was expressed as $\mu \mathrm{g}$ of quercetin equivalent (QE) per gram dry weight of powder. The result exhibited total flavonoid content of $132.05 \pm 5.23 \mu \mathrm{g} \mathrm{QE} / \mathrm{g} \mathrm{dw}$ as shown in Figurea 1a. Phenolic compound is mainly a bioactive compound in vegetables and fruits which functions to prevent oxidative stress, induce detoxification enzymes, stimulate immune system, decrease the risk of cancers, inhibit malignant transformation and carcinogenic mutations, as well as, reduce proliferation of cancer cells [36-42].

\section{Antioxidative capacity of MJP}

Antioxidative capacity of mixed low potassium vegetables and fruits juice powder determined by DPPH, FRAP and ABTS assay were presented in Figure 1b. These assays were expressed as $\mu$ mole of trolox equivalent (TE) per gram of dry weight powder. The MJP showed strongest reducing power with antioxidative capacity of $5.16 \pm 0.22 \mu$ moleTE/g dw by FRAP assay followed by ABTS method showed antioxidant capacity of $5.00 \pm 0.02 \mu$ moleTE/g $\mathrm{dw}$ and DPPH scavenging activity of MJP exhibited $3.58 \pm 0.02 \mu$ moleTE/g dw. It is known that vegetables and fruits are part of an overall healthy diet. The recommendation is a minimum of $400 \mathrm{~g}$ of fruit and vegetables per day to prevent chronic diseases due to free radical damage, as well as, alleviation of several micronutrient deficiencies [43]. The USDA recommended an ORAC unit ingestion of about 3000 to 5000 units daily to adequately saturate tissues with antioxidants [44]. Concurrently, this result has shown that the total phenolic and flavonoid quantity existed in MJP were involved in antioxidant activities evaluated using DPPH, FRAP and ABTS methods. The three antioxidant assays exhibited scavenging by electron and hydrogen atom radical, reducing power of $\mathrm{Fe}^{2+}$ to $\mathrm{Fe}^{3+}$ and hydrogen atom radical, respectively [45]. Moreover, the antioxidative potential of MJP in molecular mechanism was performed as co-treatment with $\mathrm{H}_{2} \mathrm{O}_{2}$-induced HEK-293 cell damage and MJP which was reported in different parameters including ROS production, intracellular enzymes activities, and DNA damage protection. 
(a)



(b)

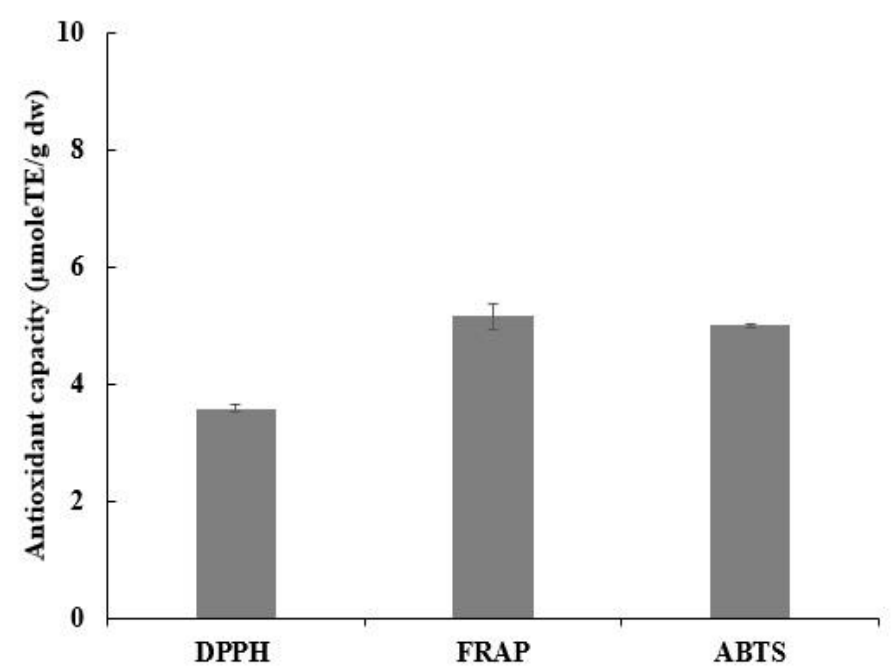

Figure 1. Total phenolic and flavonoid contents in MJP which were expressed as GAE/g dw and $\mathrm{QE} / \mathrm{g} \mathrm{dw}$, respectively (a) and Antioxidant capacity of mixed low potassium vegetables and fruits juice powder (b). Data are shown as means \pm SD from three individual experiments.

\section{Effect of MJP on cell viability}

The effect of mixed low potassium vegetables and fruits juice powder on the viability of HEK293 cells was shown in Figure 2a. The results showed that concentration of MJP from 0.1 to $10 \mathrm{mg} / \mathrm{mL}$ did not significant $(\mathrm{p}<0.05$ ) affected on cells viability when compared with control that untreated cells. However, at the concentration more than $10 \mathrm{mg} / \mathrm{mL}$ of MJP cell viability was less than $80 \%$. This due to MJP has $\mathrm{pH} 3.78$ that which effected to cell survival when the concentration more than $10 \mathrm{mg} / \mathrm{mL}$ of MJP. Therefore the $10 \mathrm{mg} / \mathrm{mL}$ of MJP was selected for further study.

\section{Effect of MJP on $\mathrm{H}_{2} \mathrm{O}_{2}$ - induced toxicity in $\mathrm{HEK}-293$ cells}

The toxicity of hydrogen peroxide $\left(\mathrm{H}_{2} \mathrm{O}_{2}\right)$ on HEK-293 cell viability was shown in Figure $2 b$. The viability of HEK-293 cells decreased significantly $(\mathrm{p}<0.05)$ with the increasing concentration of $\mathrm{H}_{2} \mathrm{O}_{2}$ ranged from 0.5 to $4 \mathrm{mmole} / \mathrm{L}$. The results showed that the half maximal inhibitory concentration $\left(\mathrm{IC}_{50}\right)$ of $\mathrm{H}_{2} \mathrm{O}_{2}$ was indicated as $1.57 \mathrm{mmole} / \mathrm{L}\left(\mathrm{R}^{2}=0.9972\right)$. Previously reported [25], $\mathrm{H}_{2} \mathrm{O}_{2}$ concentration 2 mmole/L was affected to $50 \%$ cell viability of HEK-293 cells which was close to our experiment of $\mathrm{H}_{2} \mathrm{O}_{2}$ concentration. Oxidative stress has been proposed as "an imbalance between oxidants and antioxidants in favor of the oxidants, leading to a disruption of redox signaling and control and/or molecular damage" [46]. Hydrogen peroxide $\left(\mathrm{H}_{2} \mathrm{O}_{2}\right)$ is nonradical reactive oxygen species and (ROS) that changes to highly toxic hydroxyl free radicals $(\mathrm{OH} \cdot)$ [3]. The human embryonic kidney (HEK-293) cells were used in the experiments as a demonstrated cell model to determine the antioxidative capacity effects of MJP against $\mathrm{H}_{2} \mathrm{O}_{2}$-induced toxicity and cells damage. Later, the evaluation of antioxidative capacity in HEK-293 cells was performed by a half maximal inhibitory concentration ( $\mathrm{IC}_{50}$ ) of $\mathrm{H}_{2} \mathrm{O}_{2}$-induced cells and co-treatment with different concentration of 
MJP to determine the nephroprotective effect, cellular morphological changes, intracellular ROS production, enzymatic antioxidant activity (SOD and CAT), MDA and DNA damage protection.

(a)

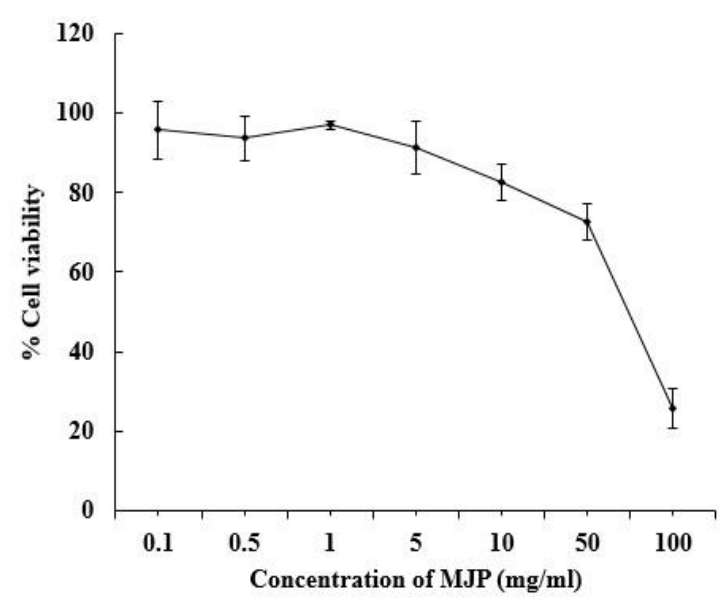

(b)

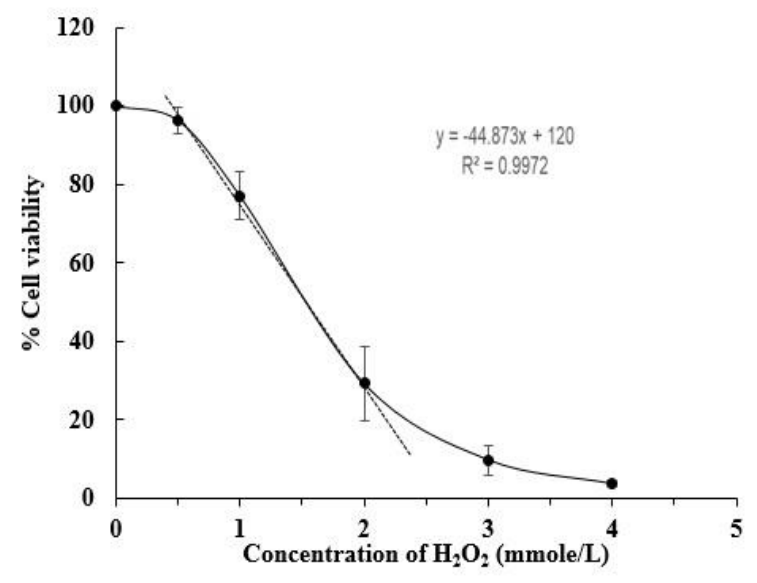

Figure 2. Cytotoxicity of mixed low potassium vegetables and fruits Juice Powder (a) and $\mathrm{H}_{2} \mathrm{O}_{2}$ (b) in HEK-293 cells. Each point represents a mean $\pm \mathrm{SD}$ of three experiments.

\section{Nephroprotective effect of $\mathrm{MJP}$ against $\mathrm{H}_{2} \mathrm{O}_{2}$ - induced toxicity}

The main purpose of this study is to evaluate the prevention property of MJP against $\mathrm{H}_{2} \mathrm{O}_{2}$ induce toxicity in HEK-293 cells. The result was shown in Figure 3a, the HEK-293 cells were exposed to MJP ranged of $0.1,0.5,1,5$ and $10 \mathrm{mg} / \mathrm{mL}$ with or without $1.57 \mathrm{mmole} / \mathrm{L}$ of $\mathrm{H}_{2} \mathrm{O}_{2}$ for $24 \mathrm{hrs}$. The result showed that cells exposed to only 1.57 mmole/ $\mathrm{L} \mathrm{H}_{2} \mathrm{O}_{2}$ showed $54.85 \%$ cell death, while the cells that were treated by $\mathrm{H}_{2} \mathrm{O}_{2}$ and MJP at concentration of 0.1 to 1 did not significantly decreased for 55.11 to $55.94 \%$ of cell death. However, the MJP 5 and 10 $\mathrm{mg} / \mathrm{mL}$ significantly $(\mathrm{p}<0.01)$ reduced cell death of $45.09 \%$ and $40.63 \%$, respectively. The result revealed that MJP at 5 and $10 \mathrm{mg} / \mathrm{mL}$ significantly $(\mathrm{p}<0.01)$ decreased apoptotic cell death compared with only $\mathrm{H}_{2} \mathrm{O}_{2}$ treatment. Similar to the present study of jaboticaba fruit peel extracts are antioxidants and exert cytoprotective effects under $\mathrm{H}_{2} \mathrm{O}_{2}$-induced oxidative stress [47]. The report from other cells such as neuronal and lung epithelial cells were protected from $\mathrm{H}_{2} \mathrm{O}_{2}$ induced oxidation by Bacopa monniera, a traditional medicinal herb that acts as an antioxidant. Therefore, it can be assumed that the antioxidant activity of a high dose of MJP diminished the $\mathrm{H}_{2} \mathrm{O}_{2}$ toxicity, of which improved the cells to survive [48].

\section{MJP moderate $\mathrm{H}_{2} \mathrm{O}_{2}$-induced cell morphological changes}

The morphological changes of $\mathrm{H}_{2} \mathrm{O}_{2}$-induced HEK-293 cells observed by a fluorescence microscope were stained with Hoechst 33342 DNA staining dye and phase contrast microscopy. The result shown in Figure $3 b$, in the $\mathrm{H}_{2} \mathrm{O}_{2}$-induced cell, the nucleus broke into small fragments and formed apoptotic bodies compared with a control with untreated cells. Moreover, the cells that were treated with $\mathrm{H}_{2} \mathrm{O}_{2}$ and MJP at the concentration of 5 and 10 $\mathrm{mg} / \mathrm{mL}$ exhibited less nuclei fragment than only $\mathrm{H}_{2} \mathrm{O}_{2}$ treated. Especially, at the concentration 
of MJP at $10 \mathrm{mg} / \mathrm{ml}$ was hardly to observed nuclei fragmentation around nucleus [29], The result showed that ferulic acid did not exhibit such nuclear condensation after pretreatment.

(a)



(b)



Figure. 3. Nephroprotective effect of mixed low potassium vegetables and fruits juice powder. Cells treated with $\mathrm{H}_{2} \mathrm{O}_{2}$ and $\mathrm{H}_{2} \mathrm{O}_{2}$ with MJP for $24 \mathrm{~h}$, cell viability data was shown as mean $\pm \mathrm{SD}(\mathrm{n}=3)$ (a.). Morphological changes of HEK-293 cells observed by fluorescence microscope after staining with Hoechst 33342 and phase contrasted microscopy (100x) (b.) and nuclei fragments showed as arrow.

\section{Effect of MJP on intracellular ROS production.}

The reactive oxygen species (ROS) production was quantified using fluorescence microplate reader, the result was shown in Figure 4a. ROS level exhibited $180.65 \%$ in the $\mathrm{H}_{2} \mathrm{O}_{2}$ treated group which was significantly $(\mathrm{p}<0.01)$ increased when compare to control normal untreated cell $(100 \%)$. The HEK-293 cells ROS production was significantly $(\mathrm{p}<0.01)$ decreased by MJP at the concentration up to 5 and $10 \mathrm{mg} / \mathrm{mL}$ of 133.22 and $129.85 \%$, respectively. However, the MJP at concentrations less than $5 \mathrm{mg} / \mathrm{mL}$ were not significant at a different ROS production compared to $\mathrm{H}_{2} \mathrm{O}_{2}$ treated group.

In order to further investigate the effects of MJP on intracellular ROS production, the ROS molecules produced in different treatments were detected by dichlorodihydrofluorescein (DCF) and visualized under a fluorescence microscope. DCF signals is the fluorescence product occurred by the substrate, hydrolyzed DCFH carboxylate anion was oxidized by intracellular ROS to form DCF. The change in fluorescence intensity $\left(\lambda_{\mathrm{em} / \mathrm{ex}}=530 / 485 \mathrm{~nm}\right)$ is directly proportional to the ROS level in the cells. The result showed that there was no 
fluorescein signal in the normal cells which were untreated cells while cells were treated by $\mathrm{H}_{2} \mathrm{O}_{2}$ showed stronger fluorescein of DCF (Fig 4b). Adding MJP in the $\mathrm{H}_{2} \mathrm{O}_{2}$-induced cells decreased DCF fluorescein signal especially when increased concentration of MJP up to 10 $\mathrm{mg} / \mathrm{mL}$ which indicated that MJP reduced ROS production. Additionally, the reported that ferulic acid substance decreased ROS production in HEK-293 cells after exposed to $\mathrm{H}_{2} \mathrm{O}_{2}$ [28]. This finding reported [30] that the HEK-293 cells of Thai fruits juice significantly decreased the ROS level. Similar to present study [25] found that Euphorbia bivonae polysaccharides diminished ROS production in HEK-293 cells compare with only $\mathrm{H}_{2} \mathrm{O}_{2}$ induced cells.

\section{Effect of MJP on enzymatic antioxidant activity and lipid peroxidation}

The effect of MJP on enzymatic antioxidant activities in $\mathrm{H}_{2} \mathrm{O}_{2}$ induced HEK-293 cells was shown in Fig. 5. Superoxide dismutase (SOD) activity significantly $(\mathrm{p}<0.01)$ decreased $39.78 \%$ in $\mathrm{H}_{2} \mathrm{O}_{2}$ treatment compared with control untreated cells. Co-treatment of $10 \mathrm{mg} / \mathrm{mL}$ MJP and $\mathrm{H}_{2} \mathrm{O}_{2}$ significantly increased SOD activity, but not significantly different in MJP concentration less than $10 \mathrm{mg} / \mathrm{mL}$ (Figure 5a). Catalase (CAT) activity presented in HEK-293 cells treated with $\mathrm{H}_{2} \mathrm{O}_{2}$ was also significantly $(\mathrm{p}<0.01)$ decreased $(78.48 \%)$ compared with control cells. However, MJP at the concentration of $0.1-10 \mathrm{mg} / \mathrm{mL}$ exhibited significantly increased CAT activity for 2.81 to $10.04 \%$ compared to only $\mathrm{H}_{2} \mathrm{O}_{2}$ (Figure 5b). In addition, lipid peroxidation was expressed as MDA contents (by product of lipid peroxidation). The results showed that significantly ( $\mathrm{p}<0.01$ ) increased MDA of $72.23 \%$ in $\mathrm{H}_{2} \mathrm{O}_{2}$ treated group, but in the co-treatment with $0.1-10 \mathrm{mg} / \mathrm{mL}$ MJP significantly lower MDA contents than $\mathrm{H}_{2} \mathrm{O}_{2}$ treated group of 11.74 to $34.71 \%$ (Figure 5c) [25, 29, 30]. The most important protection mechanisms against the free radicals or oxidants in the body are endogenous intracellular antioxidant enzymes such as superoxide dismutase (SOD) changes superoxide radical $\left(\mathrm{O}_{2}{ }^{{ }^{-\cdot}}\right)$ to $\mathrm{H}_{2} \mathrm{O}_{2}$ and $\mathrm{O}_{2}$ after that catalase (CAT) convert $\mathrm{H}_{2} \mathrm{O}_{2}$ in to water $\left(\mathrm{H}_{2} \mathrm{O}\right)$ and $\mathrm{O}_{2}$ otherwise $\mathrm{H}_{2} \mathrm{O}_{2}$ transfer to $\mathrm{HO}$, lead to lipid peroxidation presence malondialdehyde (MDA) [3].

(a)

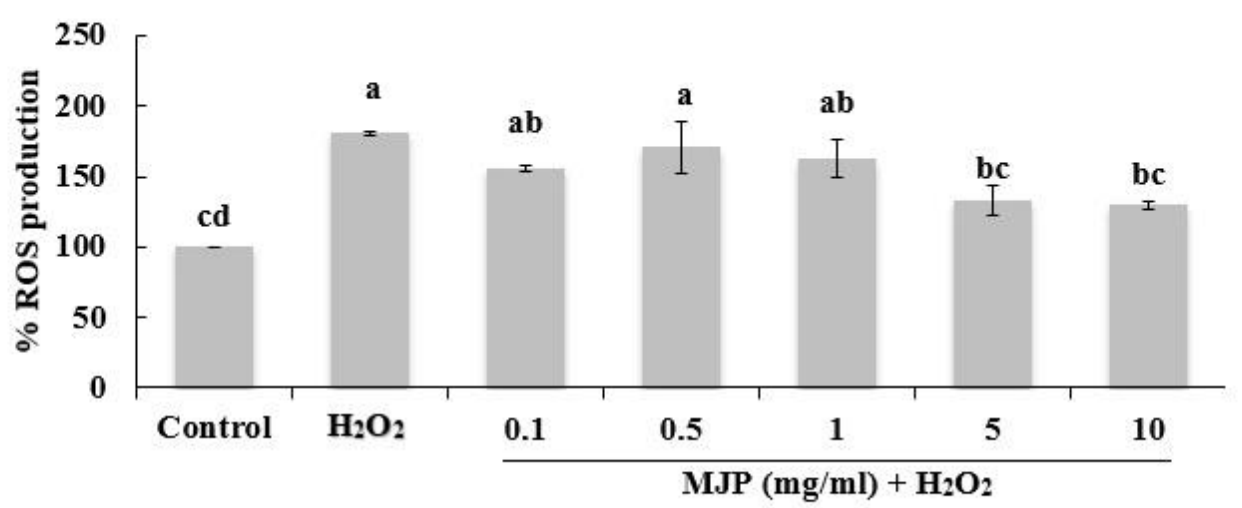

(b)

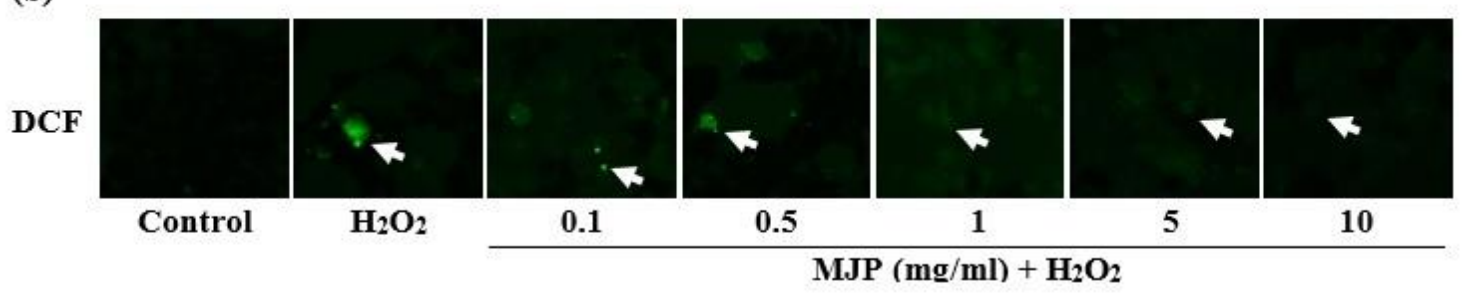

Figure. 4. Effect of MJP on $\mathrm{H}_{2} \mathrm{O}_{2}$-induced ROS production in HEK-293 cells. Cells treated with $\mathrm{H}_{2} \mathrm{O}_{2}$ and $\mathrm{H}_{2} \mathrm{O}_{2}$ with MJP for 30 minutes. Cells were incubated with DCFH-DA. (a.) The intracellular 
ROS production was expressed as a percentage of control and shown as mean $\pm \mathrm{SD}(\mathrm{n}=3)$. A value same superscript is not significant $(\mathrm{p}<0.05)$. (b.) DCF represented intracellular ROS observed by fluorescence microscope (100X)

This result exhibited MJP enhanced SOD and CAT to protect the cells from oxidation, and the same way MJP decreased lipidperoxidation that showed MDA decreased. This result may occur by inhibition of MJP that scavenged HO or inhibited fenton's reaction, more understanding DNA damage protection was examined.

\section{DNA damage protection of MJP}

The agarose gel electrophoresis of DNA damage protection was shown in Figure 6a and the calculated intensity DNA band from the gel was shown in Figure 6b. The DNA damage was induced by Fenton's reagent, a solution of hydrogen peroxide $\left(\mathrm{H}_{2} \mathrm{O}_{2}\right)$ with ferrous iron as a catalyst. The genomic DNA extracted from HEK-293 cells showed up as a dark band on agarose gel electrophoresis (lane 1 in Figure 6a and control in Figure 6b). The DNA incubated with Fenton's reagent was shown in lane 2 and 3, which lack of DNA in both lanes implied that the genomic DNA has been thoroughly degraded. As in the concentration of MJP was increased in lanes 3 to 7 ( $0.1,0.5,1,5$ and 10 respectively), the presence and darkness of the DNA band were increased, as well as, the increased of calculated intensity indicating MJP can infer a protective effect against Fenton's agent-induced DNA damage. The result which agreed with the previous study. This DNA survival can be explained by reducing level of ROS production which cause of cell injury and damage [31].

(a)

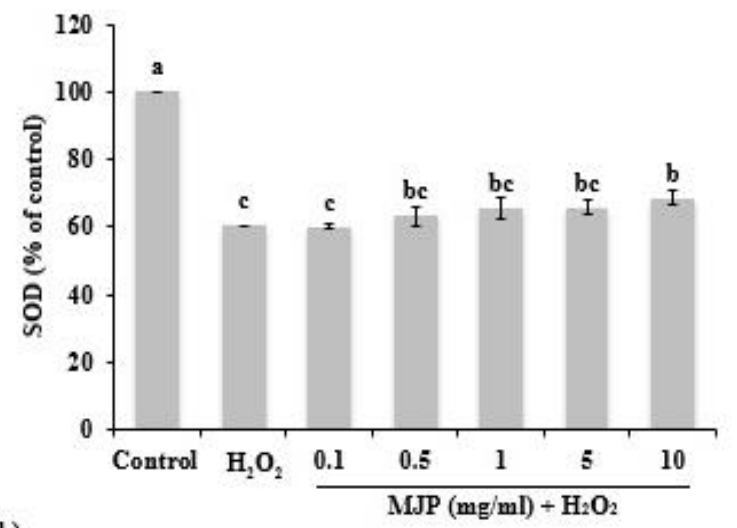

(b)

(c)
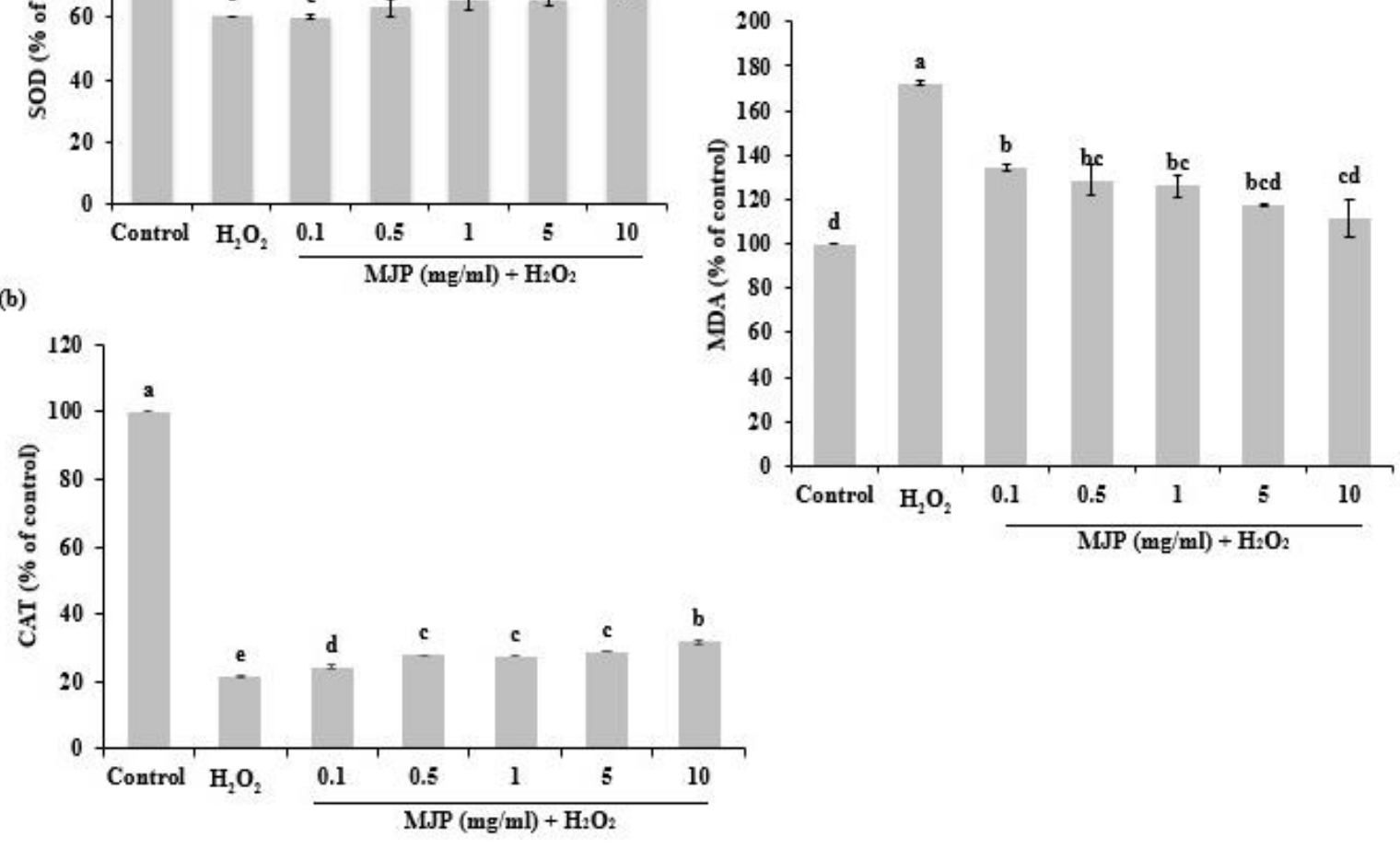
Figure 5. Effect of MJP on superoxide dismutase (SOD), catalase (CAT) activity and malondialdehyde (MDA) production in $\mathrm{H}_{2} \mathrm{O}_{2}$-induced HEK-293 cells. Data represents mean \pm $\mathrm{SD}$. The difference letters on the bars are significantly difference $(\mathrm{p}<0.05)$ according to Turkey's test.

(a)

\begin{tabular}{cccccccc}
\hline Lane & 1 & 2 & 3 & 4 & 5 & 6 & 7 \\
\hline Fenton's reagent & - & + & + & + & + & + & + \\
\hline MJP $(\mathbf{m g} / \mathbf{m l})$ & - & - & 0.1 & 0.5 & 1 & 5 & 10 \\
\hline
\end{tabular}

(b)
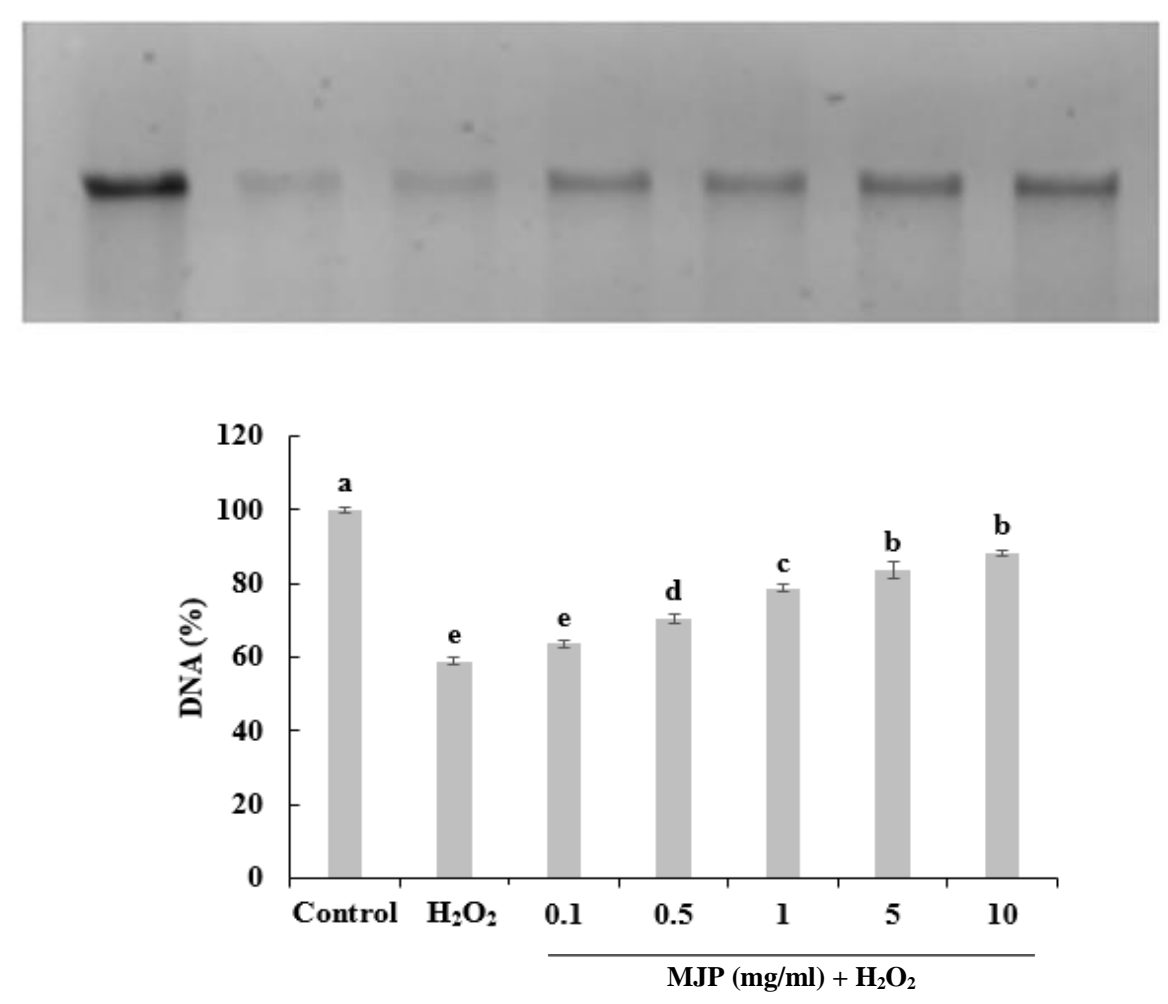

Figure. 6. Visualization of the DNA damage protection in the present and absence of MJP on agarose gel electrophoresis (a) and the quantified band intensity for the genomic DNA (b). Lane 1, DNA incubated without Fenton's reagent; Lane 2, DNA incubated with Fenton's reagent; Lanes 37, DNA incubated with Fenton's reagent and MJP of 0.1, 0.5, 1, 5 and 10, respectively.

\section{CONCLUSION}

The present study was accomplished antioxidative capacity of mixed low potassium vegetables and fruits juice powder (MJP) on molecular mechanism in HEK-293 cells against the hydrogen peroxide toxicity. The treated cells responded to cytoprotective effects and DNA damage protection of MJP, reduced ROS production, induced intracellular enzymatic antioxidant activity such as SOD and CAT, and reduced the end product of lipid peroxidation (MDA). Taken together, the results provided comprehensions of antioxidant effects of MJP which could take as a novel functional juice powder for individual limiting potassium and liquid uptake.

List of Abbreviations: MJP, mixed low potassium vegetables and fruits powder; ROS, reactive oxygen species; RNS, reactive nitrogen species; SOD, superoxide dismutase; CAT, catalase; MDA, malondialdehyde

Completing Interests: There are no conflicts of interest to declare. 
Authors' Contributions: Nualpun Sirinupong and Kanyanatt Kanokwiroon designed the research; Matthawan Khamhae the research and draft manuscript; Worrapanit Chansuwan, Nualpun Sirinupong and Kanyanatt Kanokwiroon the data. Nualpun Sirinupong edited the manuscript and had primary responsibility for the final content. All authors read and approved the final version of the manuscript

Acknowledgements and Funding: This work was supported by Food Innovation and Research Institute (FIRIN) budget, (PHY601164S). Interdisciplinary Graduate School of Nutraceutical and Functional Food, Prince of Songkla University.

\section{REFERENCES}

1. Corpas F.J, Barroso J.B. Nitro-oxidative stress vs oxidative or nitrosative stress in higher plants. New Phytologist, 2013. 199(3) 633-635. http:/doi: 10.1111/nph.12380

2. Liguori I, Russo G, Curcio F, Bulli G, Aran L, Della M.D. et al. Oxidative stress, aging, and diseases. Clinical interventions in aging, 2018. 13, 757-772. http://doi: 10.2147/CIA.S158513

3. Biswas S.K. Does the interdependence between oxidative stress and inflammation explain the antioxidant paradox? Oxidative Medicine and Cellular Longevity, 2016. http://doi: 10.1155/2016/5698931

4. Sundaram S. P. M, Nagarajan S, Devi A.J.M. Chronic Kidney Disease-Effect of Oxidative Stress. Chinese Journal of Biology, 2014. http://doi: $10.1155 / 2014 / 216210$

5. Sung C.C, Hsu Y.C, Chen C.C, Lin Y.F, Wu C.C. Oxidative stress and nucleic acid oxidation in patients with chronic kidney disease. Oxidative Medicine and Cellular Longevity, 2013. https://doi.org/10.1155/2013/301982

6. Boeing H, Bechthold A, Bub A, Ellinger S, Haller D, Kroke A, et al. Critical review: vegetables and fruit in the prevention of chronic diseases. European journal of nutrition, 2012. 51(6), 637-663. http://doi: 10.1007/s00394-012-0380-y

7. Jun M, Venkataraman V, Razavian M, Cooper B, Zoungas S, Ninomiya T, et al. 2012. Antioxidants for chronic kidney disease. The Cochrane database of systematic reviews, 10, Cd008176. doi: 10.1002/14651858.CD008176.pub2

8. Marques de Mattos A, Afonso Jordao A, Abrao Cardeal da Costa J, Garcia Chiarello P. Study of Protein Oxidative Stress, Antioxidant Vitamins and Inflammation in Patients Undergoing either Hemodialysis or Peritoneal Dialysis. Int J Vitam Nutr Res, 2014. 84(5-6), 261-268. http://doi: 10.1024/0300-9831/a000212

9. Chen J, Siriki R. Antioxidants Therapy for Patients with Chronic Kidney Disease: A Question of Balance. American Journal of Nephrology, 2015. 42(4), 318-319. http://doi: 10.1159/000441628

10. Cai Y, Luo Q, Sun M, Corke H. Antioxidant activity and phenolic compounds of 112 traditional Chinese medicinal plants associated with anticancer. Life Sci, 2004. 74(17), 2157-2184. http://doi: 10.1016/j.lfs.2003.09.047

11. Zhang L, Ravipati A.S, Koyyalamudi S.R, Jeong S.C, Reddy N, Smith P.T, Wu M.J. Antioxidant and anti-inflammatory activities of selected medicinal plants containing phenolic and flavonoid compounds. Journal of agricultural and food chemistry, 2011. 59(23), 12361-12367. 
12. Fu L, Xu B.T, Xu X.R, Gan R.Y, Zhang Y, Xia E.Q, Li H.B. Antioxidant capacities and total phenolic contents of 62 fruits. Food Chemistry, 2011. 129(2), 345-350. http://doi: 10.1016/j.foodchem.2011.04.079

13. Lutz M, Hernández J, Henríquez C. Phenolic content and antioxidant capacity in fresh and dry fruits and vegetables grown in Chile. CyTA - Journal of Food, 2015. 13(4), 541-547. http://doi: 10.1080/19476337.2015.1012743

14. Álvarez R, Araya H, Navarro-Lisboa R, Lopez de Dicastillo C. Evaluation of Polyphenol Content and Antioxidant Capacity of Fruits and Vegetables Using a Modified Enzymatic Extraction. Food technology and biotechnology, 2016. 54(4), 462-467. http://doi: 10.17113/ftb.54.04.16.4497

15. Fu L, Xu B.T, Xu X.R, Qin X.S, Gan R.Y, Li H.B. Antioxidant capacities and total phenolic contents of 56 wild fruits from South China. Molecules, 2010. 15(12), 8602-8617. http://doi: 10.3390/molecules 15128602

16. Tinrat S. Antioxidant activities and total phenolic content of multi-colored fruits and vegetables in Thailand. KKU Research Journal, 2016. 21(1), 1-11. http://doi: 10.14456/kkurj.2016.1

17. De Nicola L, Zoccali, C. Chronic kidney disease prevalence in the general population: heterogeneity and concerns. Nephrol Dial Transplant, 2016. 31(3), 331335. http://doi: 10.1093/ndt/gfv427

18. Vejakama P, Insathit A, Thakkinstian A. Chronic kidney disease prevalence in Thailand. 2015. [http://kb.hsri.or.th/dspace/handle/11228/4345] Retrieved December 31, 2019.

19. Ash S, Campbell K, MacLaughlin H, McCoy E, Chan M, Anderson K, et al. Evidence based practice guidelines for the nutritional management of chronic kidney disease. Nutrition \& Dietetics, 2006. 63, S33-S45.

20. Sousa B.A, Correia R.T.P. Phenolic content, antioxidant activity and antiamylolytic activity of extracts obtained from bioprocessed pineapple and guava wastes. Brazilian Journal of Chemical Engineering, 2012. 29(1), 25-30.

21. Rebaya A, Belghith S.I, Baghdikian B, Leddet V.M, Mabrouki F, Olivier E, et al. Total phenolic, total flavonoid, tannin content, and antioxidant capacity of Halimium halimifolium (Cistaceae). Journal of applied pharmaceutical science, 2014. 5(1), 5257.

22. Pyo Y. H, Jin Y.J, Hwang J.Y. Comparison of the effects of blending and juicing on the phytochemical's contents and antioxidant capacity of typical Korean kernel fruit juices. Preventive nutrition and food science, 2014. 19(2), 108.

23. Young I, Woodside J. Antioxidants in health and disease. Journal of clinical pathology, 2001. 54(3), 176-186.

24. Arnao M. B, Ca2001.o A, Acosta M. The hydrophilic and lipophilic contribution to total antioxidant activity. Food Chemistry, 2001. 73(2), 239-244.

25. Athmouni K, Belhaj D, El Feki A, Ayadi H. Optimization, antioxidant potential, modulatory effect and anti-apoptotic action in of Euphorbia bivonae polysaccharides on hydrogen peroxide-induced toxicity in human embryonic kidney cells HEK293. International journal of biological macromolecules, 2018. 116, 482-491.

26. Reshma A.K.P, Brindha P. In vitro anti-inflammatory, antioxidant and nephroprotective studies on leaves of Aegle marmelos and Ocimum sanctum. Asian J Pharm Clin Res. 2014. 
27. Kalaivani M.K, Soundararajan P, Vasanthi H.R, Sumathy A. In-vitro Nephroprotective role of Ethanolic root extract of Boerhaavia diffusa against cisplatin induced nephrotoxicity. International Journal of Phytomedicine, 2015.

28. Elumalai P, Gunadharini D, Senthilkumar K, Banudevi S, Arunkumar R, Benson C, et al. Induction of apoptosis in human breast cancer cells by nimbolide through extrinsic and intrinsic pathway. Toxicology letters, 2012. 215(2), 131-142.

29. Bian Y. Y, Guo J, Majeed H, Zhu K. X, Guo X. N, Peng W, et al. Ferulic acid renders protection to HEK293 cells against oxidative damage and apoptosis induced by hydrogen peroxide. In Vitro Cellular \& Developmental Biology-Animal, 2015. 51(7), 722-729.

30. Anantachoke N, Lomarat P, Praserttirachai W, Khammanit R, Mangmool S. Thai fruits exhibit antioxidant activity and induction of antioxidant enzymes in HEK-293 cells. Evidence-Based Complementary and Alternative Medicine, 2016.

31. Jiang Y, Han W, Shen T, Wang M.H. Antioxidant activity and protection from dna damage by water extract from pine (Pinus densiflora) bark. Preventive nutrition and food science, 2012. 17(2), 116.

32. Tonon R.V., Brabet C, Hubinger M.D. Influence of process conditions on the physicochemical properties of açai (Euterpe oleraceae Mart.) powder produced by spray drying. Journal of food engineering, 2008. 88(3), 411-418.

33. Cynthia S, Bosco J.D, Bhol S. Physical and structural properties of spray dried tamarind (Tamarindus indica L.) pulp extract powder with encapsulating hydrocolloids. International Journal of Food Properties, 2015. 18, 1793-1800.

34. Avila E.L, Rodríguez M.C, Velasquez H.J.C. Influence of maltodextrin and spray drying process conditions on sugarcane juice powder quality. Revista Facultad Nacional de Agronomía, Medellín, 2015. 68, 7509-7520.

35. Pachotikarn C. Management of food intake in dialysis patient. Thai dietetics. 2016. [http://www.thaidietetics.org/File/Share_Learn/SL20120604032110_Mgt\%20of\%2 0Food\%20intake\%20(Chanida\%20Pachotikarn\%20).pdf] Retrieved December 31, 2019.

36. Nti C.A, Hagan J, Bagina F, Seglah M. Knowledge of nutrition and health benefits and frequency of consumption of fruits and vegetables among Ghanaian homemakers. African Journal of Food Science, 2011. 5(6), 333-339.

37. Guo X, Li T, Tang K, Liu, R.H. Effect of Germination on Phytochemical Profiles and Antioxidant Activity of Mung Bean Sprouts (Vigna radiata). Journal of Agricultural and Food Chemistry, 2012. 60(44), 11050-11055. http://doi: 10.1021/jf304443u

38. Kapusta-Duch J, Kopec A, Piatkowska E, Borczak B, Leszczynska T. The beneficial effects of Brassica vegetables on human health. Roczniki Państwowego Zakładu Higieny, 2012. 63(4).

39. Naz A, Butt M.S, Sultan M.T, Qayyum M.M.N, Niaz R.S. Watermelon lycopene and allied health claims. EXCLI journal, 2014. 13, 650-660.

40. Endrizzi I, Torri L, Corollaro M.L, Demattè M.L, Aprea E, Charles M, et al. A conjoint study on apple acceptability: Sensory characteristics and nutritional information. Food quality and preference, 2015. 40, 39-48.

41. Hossain M.F, Akhtar S, Anwar M. Nutritional value and medicinal benefits of pineapple. International Journal of Nutrition and Food Sciences, 2015. 4(1), 84-88. 
42. Sun X, Baldwin E.A, Plotto A, Manthey J.A, Duan Y, Bai J. Effects of thermal processing and pulp filtration on physical, chemical and sensory properties of winter melon juice. Journal of the Science of Food and Agriculture, 2017. 97(2), 543-550.

43. WHO. Diet, nutrition, and the prevention of chronic diseases: report of a joint WHO/FAO expert consultation (Vol. 916): World Health Organization. 2003. [https://apps.who.int/iris/bitstream/handle/10665/42665/WHO_TRS_916.pdf;jsessi onid=922B5DF9256628FB4E545CD9157DF596?sequence=1] Retrieved December 31, 2019.

44. WHO. Diet, nutrition, and the prevention of chronic diseases: report of a joint WHO/FAO expert consultation (Vol. 916): World Health Organization. 2003. [https://apps.who.int/iris/bitstream/handle/10665/42665/WHO_TRS_916.pdf;jsessi onid=922B5DF9256628FB4E545CD9157DF596?sequence=1] Retrieved December 31, 2019.

45. Gülcin I. Antioxidant activity of food constituents: an overview. Archives of toxicology, 2012. 86(3), 345-391.

46. Jones D.P. Redefining oxidative stress. Antioxidants \& redox signaling, 2006. 8(910), 1865-1879.

47. da Silva Pitz H, Pereira A, Voytena A.P.L, Trevisan A.C.D, Affonso R.C.L, Ribeirodo-Valle R.M, Maraschin M. Cytoprotective Effects of Jaboticaba (Pliniaperuviana, Poir. Govaerts) Fruit Peel Extracts against H2O2-Induced Oxidative Stress. Reactive Oxygen Species, 2017. 4(11), 362-371.

48. Pandareesh M.D, Anand T, Bhat P.V. Cytoprotective propensity of Bacopa monniera against hydrogen peroxide induced oxidative damage in neuronal and lung epithelial cells. Cytotechnology, 2016. 68(1), 157-172. 